\title{
Scientific Tourism Development Bases in Armenia
}

\section{Gayane Tovmasyan}

$\mathrm{PhD}$ in Economics, Researcher at "AMBERD” Research Center of the Armenian State University of Economics, Professor at the Public Administration Academy of the Republic of Armenia, the Republic of Armenia

\section{Rubik Tovmasyan}

$\mathrm{PhD}$ in Economics, Docent at Armenian National Agrarian University, the Republic of Armenia

\begin{abstract}
Tourism is one of the most rapidly developing branches of the world economy. Scientific tourism is one of the types of tourism which is often considered as knowledge oriented or learning tourism. It is organized mainly by researchers, students, academics, scientists in order to conduct research in a specific area. Scientific tourism activities include participation in expeditions, excavations, congresses, conferences, experiments, contests and other scientific events. In this case science and tourism are connected to each other, as science development promotes tourism.
\end{abstract}

Armenia has a rich scientific heritage. Many Armenian universities, museums, observatories, laboratories, reservations may be of high interest for touristic visits. Besides, Armenian scientific centers may implement international scientific programs including international known scientists and specialists. The aim of this article is to present the essence of scientific tourism, to analyze the bases of scientific tourism development in Armenia, to find out the existing problems and find some solutions for them. At the end of the conducted analysis we have made some suggestions for advancing scientific tourism in Armenia, such as elaborating a strategic development plan of scientific tourism; developing appropriate tour packages for incoming and domestic tourists; introducing Armenia as a country of scientific tourism abroad with its rich scientific heritage and traditions; including a course about scientific tourism in educational programs of tourism specialties of higher and vocational educational institutions; improving the statistics of the sphere; organizing international scientific events, scientific research programs, conferences, forums for attracting and involving international scientists and developing tourism in Armenia.

Keywords: science, tourism, museum, observatory, reservation, expedition, research, scientific tours.

JEL Classification: Z3, L83.

\section{Introduction}

Tourism is a global phenomenon which develops very fast and is considered to be one of the largest industries all over the world. It involves more and more people year by year. The number of international tourist arrivals rose from 277 million (1980) up to 1,235 million in 2016. The total contribution of Travel \& Tourism to GDP was USD 7,613.3bn (10.2\% of GDP) in 2016 in the world. In 2016, the total contribution of Travel \& Tourism to employment was $9.6 \%$ of full employment $(292,220,000$ jobs). Visitor exports generated USD 1,401.5bn (6.6\% of total exports) in 2016. Travel \& Tourism investment in 2016 was USD 806.5bn, or $4.4 \%$ of total investment (Travel \& Tourism Economic Impact 2017 World).

Scientific tourism is one of the types of tourism. It can be defined as the type of travel the primary purpose of which is to visit scientific centers, laboratories, museums, universities, research centers for participating at scientific events, conferences, expeditions, excavations, conducting research and more. Thus, the main purpose is science and science related activities in tourism destination. In recent years the interest towards scientific tourism is growing and it may be connected with the development and progress in science and scientific innovations. So, in this article we will analyze the opportunities of scientific tourism promotion in Armenia based on existing assets.

\section{Literature review}

The term "Scientific Tourism" was used in literature for the first time in 1980. It was in the work Tropical Science and Tourism. Scientific tourism was described here as a work of the explorers in the country without proper technical equipment. According to Laing scientific tourism contains all of the attributes of the tourism 
and moreover it requires a human factor and technical equipment of the high level (Molokáčová, Molokáč, 2011).

Here we will present some different opinions about scientific tourism. Some authors consider it as a part of ecotourism, responsible tourism, voluntourism or adventure and nature based tourism. West (2008), Laarman \& Perdue (1989) and Hall \& Saarinen (2010) consider scientific tourism as a niche within alternative forms of tourism. Some relate it to learning travel (Morse, 1997) and experiential tourism (Smith, 2005). The traveler becomes an actor of his tourism experience and not just a consumer. He consumes an experience (Holbrook, Hirschman, 1982) with a personal appropriation of visited places and request thus specific services to meet his expectations. Scientific tourism is a part of "learning travel" and the expression of a change in the traditional way of travelling that could favor innovation and creativity in tourism development (CSL Sagueney - Lac St Jean, 2005).

West (2008) identifies scientific tourism as tourists who conduct scientific research in tourism destinations. Ilyina and Miezkowski (1992) use the term of 'knowledge-oriented tourism"' to describe scientific tourism. Their definition allows to include various types of tourism beyond the scientific expedition under the term scientific tourism. According to them, exploration and interpretation of the landscape are different types of scientific tourism. Scientific tourism is also a type of sustainable tourism. According to Laarman and Perdue (1989), scientific tourism provides a scientific basis for the management of natural areas, and scientific tourists are more culturally sensitive than other tourists. Although scientific tourism is considered to be a separate type of tourism, the scientific tourists use the same tourism infrastructure as other tourists.

According to the International Center for Pedagogical Sciences (CIEP), scientific tourism has three phases, which do not mutually exclude each other: exploration, investigation and interpretation (or learning). In the exploration phase, scientific expeditions and extreme adventurers expand their knowledge about the region. In the investigation phase, scientific inquiry is used to learn more about people and environments. During the interpretation phase, the knowledge gained from the previous phases is used to inform tourism and tourism products (Slocum, Kline, Holden, 2015).

The most famous scientific tourism centers in the world are the follows: Massachusetts Institute of Technology, Harvard University, University of Cambridge, University of Oxford, Stanford University, Yale University, University of Chicago, Imperial College London, California Institute of Technology, Princeton University, University of Pennsylvania, Columbia University, University of Toronto and many other universities, the European Organization for Nuclear Research in Geneva, National Physical Laboratory in the United Kingdom, Rutherford Appleton Laboratory in the United Kingdom, Brookhaven National Laboratory, Argonne National Laboratory, Fermi National Accelerator Laboratory, Lawrence Berkeley National Laboratory, Pacific Northwest National Laboratory, SLAC National Accelerator Laboratory, Thomas Jefferson National Accelerator Facility, Princeton Plasma Physics Laboratory and other laboratories, observatories: European Space Agency's Columbus Control Centre, University Observatory Vienna, Mt Graham International Observatory, Fred Lawrence Whipple Observatory, Lowell Observatory, Kitt Peak National Observatory, McDonald observatory in North America, South African Astronomical Observatory, SALT Telescope, etc, and museums: Nobel Museum in Stockholm, Marie Curie Museum in Warsaw, Science Museum in London, Auto \& Technik Museum, National Museum of Mathematics, Space Center Houston, Leonardo da Vinci Museum of Science and Technology, Kennedy Space Center, etc.

\section{Methods}

As mentioned above, the purpose of the research is to study the essence of scientific tourism as a separate type of tourism and to analyze the problems and prospects of scientific tourism development in the Republic of Armenia.

The object of the research is scientific tourism and its main assets in Armenia.

The subject of this research are development issues and bases of scientific tourism in Armenia.

The main methods used in the research are as follows: analysis and synthesis, micro and macro analysis, statistical analysis and graphical methods.

In the research a variety of data are used from the National Statistical Service of RA, The World Travel \& Tourism Council (WTTC) and other national and international organizations, state organs, etc. 


\section{Discussion and results}

In Armenia tourism was anounced as a main sector of economy. The governmental policy objectives of tourism are determined by the law of the Republic of Armenia "About tourism and tourist activities" (2003) and by the Tourism Development Plan (2008). The purpose of the governmental policy in this sphere is to enhance touristic contributions in the national fund, balanced regional development, growth of living standards of population, as well as in the process of poverty reduction which may be conditioned by creating job opportunities, increasing the number of tourist visits and the income from tourism (Tourism Development Plan, 2008, p. 28). In Armenia, the state administration body of tourism sphere is the State Tourism Commitee of the Ministry of Economic Development and Investments, which is responsible for the development and implementation of the state policy in the sphere.

In 2017 1,494,779 tourists visited Armenia (Social-Economic Situation of the RA, 2017), which is 18.7\% more than last year (Appendix, Figure 1). In 2017 January-September the number of domestic tourists in Armenia counted to be 944,937 (Social-Economic Situation in 2017 January-October of the RA).

However it should be mentioned that the data about the purpose of incoming and domestic tourists, provided by the National Statistical Service of the RA is divided into rest and leisure, business, medical and education types, and include only the number of tourists who stayed in hotel facilities. The education tourists are students from other countries who study in Armenian universities. Thus, here we do not have any information about the number of scientific tourists, beside, the tourists may stay not only in hotels, but also at rented houses or at their relative's or friend's houses.

In Armenia the direct contribution of Travel \& Tourism to GDP was USD 0.4bn, 3.8\% of total GDP in 2016, and the total contribution was USD 1.5bn, $14.0 \%$ of GDP in 2016. In 2016 Travel \& Tourism directly supported 38,500 jobs (3.3\% of total employment), and the total contribution of Travel \& Tourism to employment, including jobs indirectly supported by the industry was $12.5 \%$ of total employment (143,500 jobs). Visitor exports generated USD $918.4 \mathrm{mn}, 28.0 \%$ of total exports in 2016. Travel \& Tourism investment in 2016 was USD $0.1 \mathrm{bn}, 4.4 \%$ of total investment (Travel \& Tourism Economic Impact 2017 Armenia).

Armenia is a part of the ancient world, and its history, archeology, astronomy, geology are worth studying. The scientific history and potential of Armenia, indeed, are prerequisites for the development of scientific tourism in our country. To illustrate the scientific tourism potential of Armenia, we may present the main places worth visiting by scientific tourists:

$>$ Archeological sites - Agarak Early Bronze Age complex in Agarak Village, Ruins of Argishtikhinili in Armavir region, Ukhtasar in Syunik Region, Voskehat Patterns in Aragatsotn region, Medieval Capital Dvin Ruins in Ararat region, Historical and cultural preservation “Zorats karer' Settlement in Syunik,

$>$ Medieval universities - Historical and cultural museum-reservation of the University of Gladzor in Vernashen village of Vayots Dzor, Sanahin Monastery in Lori, Tatev Monastery in Syunik,

$>$ Scientific organizations - The Byurakan Astrophysical Observatory after V. Hambardzumyan, AI. Alikhanian National Science Laboratory (Yerevan Physics Institute), Institute of Botany of the NAS RA, Scientific Center of Zoology and Hydroecology, Institute for Informatics and Automation Problems of NAS RA, Institute of Molecular Biology, CANDLE Synchrotron Research Institute, The Institute for Physical Research, The Institute of Radiophysics and Electronics, The Aragats Space Environmental Center, Yerevan State University, etc.

$>$ Scientific Museums - History Museum of Armenia, Yerevan History Museum, History Museums of Aparan, Kapan, Koghb, Sisian, Spitak, Victor Hambardzumyan House-Museum, Historical-Cultural Museum-Reservation of Zvartnots, Echmiadzin Historical and Ethnographic Museum, The Geological Museum of Gavar, Historical and archeological museum-reservation of Metsamor, Museum of Folk Arts of Armenia, State Museum of Nature of the RA, The Armenian Genocide Museum - Institute, Museum of Space, Museum of Fine Arts of Shoushi, Memorial complex of Sardarapat Battle, National museum of Armenian Ethnography and History of Liberal struggle, Lori-Pambak Geological Museum, Erebuni Historical and Archeological Museum-Reserve, The Artsakh State Historical-Geological Museum, Geological Museum of Yeghegnadzor, Historical and cultural museum-reservation of Garni, The Mesrop Mashtots Institute of Ancient Manuscripts (Matenadaran), Museum of Science and Technology, etc. 
$>$ Reservations - Khosrov forest State Reserve, Historical and cultural preservation of "Lori berd", Historical and architectural reservation of Goshavank, Shikahogh State Reserve, Historical and natural reservation of Arpi (Armenian Scientific Tourism).

Armenia is one of the cradles of ancient science, including the astronomical knowledge. Byurakan Astrophysical Observatory is a modern astronomical centre, one of the most famous observatories in the former Soviet Union, as well as the Euro-Asian Continent. The Observatory is also scientific tourism attraction. It was founded in 1946 by outstanding scientist Viktor Hambartsumian. New ideas on birth and evolution of stars and nebulae in stellar associations, activity of galactic nuclei, new theoretical approaches have been developed by him. Stellar associations, numerous active galaxies and quasars, flare and T Tau type stars, Novae and Supernovae, and many other objects have been discovered in Byurakan. The famous Byurakan surveys have been conducted here as well. Byurakan Astrophysical Observatory actively collaborates with international observatories. The Observatory has 95 associates, including 45 astronomers. Byurakan Observatory is recognized by the scientific community as one of the main centres for astrophysical research. The conceptions and ideas proposed in Byurakan have found their further elaboration in many observatories, the new objects discovered in Byurakan are observed worldwide by famous astrophysicists (Byurakan Astrophysical Observatory).

In 2014 the "Scientific Tourism in Armenia" initiative was created in Armenia, the main goal of which is to unite representatives of scientific organizations and tourism agencies to ensure the formation of Armenia as a favorable and attractive country for scientific tourism and proper presentation of Armenian science in domestic and foreign markets from the point of view of tourism (Armenian Institute of Tourism).

According to National Statistical Service data there were 106 museums in the Republic of Armenia in 2016, the number of visits was 2,276.5 thousand in a year (Statistical yearbook of Armenia, 2017), and the number of scientific organizations was 69 (Statistical yearbook of Armenia, 2017), but it is not clear what part of the museum visitors are incoming tourists, as well as which part of the scientific-technical and research work carried out in the scientific organizations has an international character and how was the involvement of international scholars.

Some tourism agencies in Armenia offer archeological, geological, scientific tours (Archaeological tour in Armenia), some agencies include in a touristic package tours to Byurakan Observatory, Zorats Krazer. Byurakan Observatory has packages of proposals for both short-term and long-term visits for 3-7 days. Daytime and evening short visits include a tour to the $2.6 \mathrm{~m}$ telescope and observations with small telescopes in night time, long visits include popular lectures or films, and lunch, and visits for 2 and more days include additional tours to the observatory and Byurakan area (Offered packages in Byurakan Astrophysical Observatory). However, because of the lack of accurate information, we can not say how many inbound and outbound tourists use these tours, how is the demand. And from the conversation with travel agencies organizing these tours, it becomes clear that these tours are organized in case of demand (both for domestic and inbound tourists), and it does not occur regularly. Moreover, the cost of the tours varies between 305,000320,000 AMD for one inbound tourist, which includes mainly overnight accommodation, inner transportation, guided tour, meal and entrance fees.

Thus, we may resume the main problems that hinder scientific tourism development in Armenia. First of all, as it is clear from the article, we don't have accurate data about the number of scientific tourists. Armenia is nor presented abroad as a science country with its scientific rich heritage. Comprehensive approaches in number of directions should be done to develop scientific tourism in Armenia.

\section{Conclusion and suggestions}

Taking into account Armenia's potential to become a country of scientific tourism, we may say that for the development of scientific tourism it is necessary:

$>$ To develop a strategic development plan of scientific tourism, based on the resources of all of the above listed scientific organizations.

To develop appropriate packages for inbound and domestic tourists.

$>$ To carry out active marketing policy to introduce Armenia as a country of scientific tourism, with its rich scientific heritage and traditions. 
$>$ To include "Scientific tourism" course in the curricula of educational programs of tourism specialties of universities.

$>$ To organize visits to scientific organizations and museums for students and school children, as they should realize in which science community they live, what they can do to develop Armenian science.

$>$ Take steps to improve the statistics in this area, as it is not clear how many incoming and domestic scientific tourists we have, how many tourists are included in scientific works, etc.

$>$ To organize international scientific events, as well as to activate the activities of Armenian research centers in the direction of organizing international scientific research programs, in order the scientific tourism not only have the form of cognitive visits, but also involve international scientists, specialists for conducting mutual scientific, archeological and geological research, which will also contribute to the increase of Armenia's popularity as the country of scientific tourism in the world.

Thus, the above mentioned steps will contribute to scientific tourism promotion in Armenia.

\section{References}

1. Archaeological Tour in Armenia. Available online: http://onewaytour.com/hy/incomingtours/hnagitakan-tur-hayastanum/.

2. Archaeological tour: Pagan Armenia. Available online: https://barevarmenia.com/am/armenia_tours/tour114.

3. Armenian Institute of Tourism. Available online: http://www.ait.am/?id=147\&lng=3.

4. Armenian Scientific Tourism. Available online: https://www.aras.am//ArmSciTourism/reservations.php.

5. Byurakan Astrophysical Observatory, Scientific Tourism Center. Available online: https://www.aras.am//SciTourism/eng/index.php.

6. CSL Sagueney - Lac St Jean (2005). Tourisme Scientifique, pour voyager autrement. Comité Régional en Tourisme Scientifique, Sagueney - Lac St Jean. 17 p.

7. Hall, M. \& Saarinen, J. (2010). Polar tourism: Definitions and dimensions. Scandinavian Journal of Hospitality and Tourism, 10(4), 448-467.

8. Holbrook, M. B. and Hirschman, E. C. (1982). The Experiential Aspects of Consumption: Consumer Fantasies, Feelings and Fun. Journal of Consumer Research, 9, 132-140.

9. Ilyina, L. and Mieczkowski, Z. (1992). Developing scientific tourism in Russia. Tourism Management, 13(3), 327-331.

10. Laarman, J. \& Perdue, R. (1989). Science tourism in Costa Rica. Annals of Tourism Research, 16(2), 205-215.

11. Molokáčová L., Molokáč Š. (2011) Scientific tourism, Tourism in Science or Science in Tourism. Acta Geoturistica, 2(1), 41-45.

12. Morse, M. (1997). All the world's a field: a history of the scientific study tour. Progress in Tourism and Hospitality Research, 3(3), 257-269.

13. Offered packages in Byurakan Astrophysical Observatory. Available online: https://www.aras.am//SciTourism/arm/tours.php

14. Slocum S., Kline C., Holden A. (2015). Scientific Tourism: Researchers as Travellers, p. 119.

15. Smith, W. L. (2005). Experiential tourism around the world and at home: definitions and standards. International Journal of Services and Standards, 2(1), 1-14.

16. Socio-Economic Situation of the RA (January-December 2017). p. 132. Available online: http://armstat.am/file/article/sv_12_17a_421.pdf.

17. Social-Economic Situation of the RA 2010-2018. Available online: www.armstat.am.

18. Socio-Economic Situation in 2017 (2017). January-October of the RA. p. 119, Available online: http://armstat.am/file/article/sv_10_17a_432.pdf.

19. Statistical yearbook of Armenia (2017). p. 146, 150. Available online: http://armstat.am/file/doc/99504493.pdf.

20. The law of the Republic of Armenia "About tourism and tourist activities" (2003).

21. Tourism Development Plan of the RA (2008). p. 28.

22. Travel \& Tourism Economic Impact 2017 Armenia. Available online: https://www.wttc.org//media/files/reports/economic-impact-research/countries-2017/armenia2017.pdf. 
23. Travel \& Tourism Economic Impact 2017 World. Available online: https://www.wttc.org//media/files/reports/economic-impact-research/regions-2017/world2017.pdf.

24. West, P. (2008). Tourism as science and science as tourism. Current Anthropology, 49(4), 597-626.

\section{Appendix}

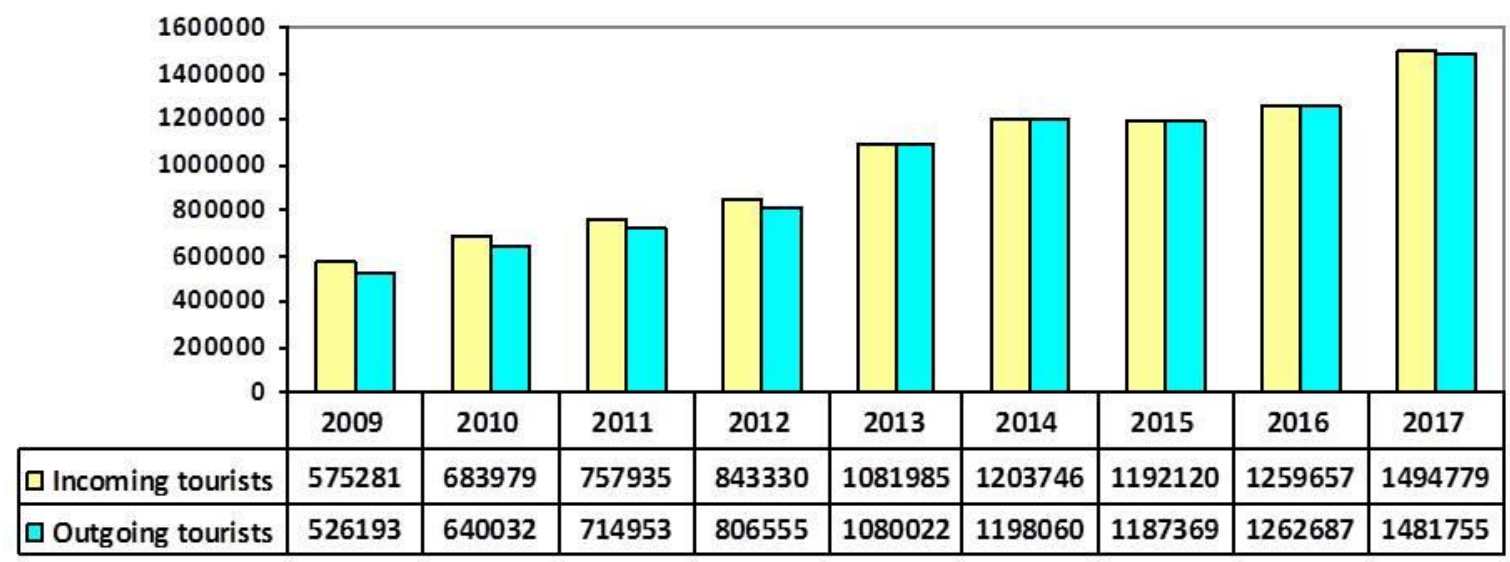

Figure 1. The number of incoming and outgoing tourists of the Republic of Armenia, 2009-2017 (Social-Economic Situation of the RA, 2010-2018) 